\title{
Editorial
}

\section{Is India prepared for an impending epidemic of cancers?}

\author{
Harshal T. Pandve ${ }^{1}$, Purushottam A. Giri ${ }^{2 *}$
}

\begin{abstract}
${ }^{1}$ Department of Community Medicine (PSM), Smt. Kashibai Navale Medical College, Narhe, Pune, Maharashtra, India ${ }^{2}$ Department of Community Medicine (PSM), Rural Medical College of Pravara Medical Institute of Medical Sciences (Deemed University), Loni, Maharashtra, India
\end{abstract}

\author{
*Correspondence: \\ Dr. Purushottam A. Giri, \\ E-mail: drpgiri14@gmail.com,dr_harshalpandve@yahoo.co.in
}

Copyright: (C) the author(s), publisher and licensee Medip Academy. This is an open-access article distributed under the terms of the Creative Commons Attribution Non-Commercial License, which permits unrestricted non-commercial use, distribution, and reproduction in any medium, provided the original work is properly cited.

Cancer can have profound social and economic consequences for people in India, often leading to family impoverishment and societal inequity. Roughly one million new cases of cancer are added every year in India, which is one-fourth of that recorded in Europe. ${ }^{1}$ Recently published India's National Health Profile 2013, projected that by 2020 India will see a $21 \%$ rise on an average in the incidence of cancer with a $19 \%$ increase in cancer among men, and a $23 \%$ increase among women. Data from 25 population-based registries across the country was analysed and extrapolated to reach the projections. The incidence of mouth cancers will rise by $51 \%, 48 \%$ increase in the incidence of prostate cancers, $31 \%$ for liver cancers and $22 \%$ for lung cancers. Cancers of the brain, hypopharynx and oesophagus will dip very marginally. Gall bladder cancers will increase $45 \%$, and ovarian cancers $28 \%$. All cancers are projected to rise in women, including cervical and breast cancers, which will continue to be the two most common types. ${ }^{2}$

This report is an indication of an impending epidemic of cancers in India. The basic question is whether India prepared for such kind of an epidemic? The answer in current scenario is definitely no. As per Mallath et al. nearly $70 \%$ cancer patients die in India. This ratio indicates that fewer than $30 \%$ of Indian patients with cancer survive five years or longer after diagnosis. It is due to low rates of early-stage detection and poor treatment outcomes. ${ }^{1}$ The infrastructure and trained manpower required for early detection and management of cancer in India is extremely inadequate. The numbers of specialised cancer hospitals in the country are negligible compared to number of cancer patients. For an example India have 2-5 million people per radiotherapy machine, compared to fewer than 250000 people per machine in high-income countries. ${ }^{1}$ Poor Indians cannot afford the treatment of private sector. Even though there are legislations regarding tobacco related products majority of India's cancer burden is related to tobacco. This indicates that only laws and legislations are not effective enough. Palliative care is the active total care of patients in advanced and incurable stages of cancer. More than $70 \%$ of all cancer patients in India require palliative care for relief of pain, other symptoms, and psychosocial distress. Palliative care has limited coverage in India. Obstacles in the growth of palliative care in India are too many and not only include factors like population density, poverty, geographical diversity, restrictive policies regarding opioid prescription, workforce development at base level, but also limited national palliative care policy and lack of institutional interest in palliative care. ${ }^{3}$ There is also extremely poor awareness about palliative care amongst the cancer patient's caregivers. $^{4,5}$

To conclude, the projections of National Health Profile 2013 regarding cancer incidence in India are really alarming. Urgent multi-pronged initiatives are required to effectively address this impending epidemic of cancer.

\section{REFERENCES}

1. Central Bureau of Health Intelligence - India. National health profile, 2013. Available at: http://www.cbhidghs.nic.in/writereaddata/mainlinkF ile/Health\%20Status\%20Indicators-2013.pdf. Accessed 24 July 2014.

2. Mallath MK, Taylor DG, Badwe RA, Rath GK, Shanta V, Pramesh CS, et al. The growing burden of cancer in India: epidemiology and social context. Lancet Oncol. 2014;15(6):e205-12.

3. Khosla D, Patel FD, Sharma SC. Palliative care in India: Current progress and future needs. Indian $\mathrm{J}$ Palliat Care. 2012;18:149-54. 
4. Pandve HT, Fernandez K, Chawla PS, Singru SA. Palliative care: need of awareness in general population. Indian J Palliat Care. 2009;15:162-3.

5. Giri PA, Phalke DB. Knowledge regarding palliative care amongst medical and dental postgraduate students of medical university in western Maharashtra, India. CHRISMED J Health Res. 2014;1:250-3.

DOI: $10.5455 / 2394-6040 . i j c m p h 20150201$

Cite this article as: Pandve HT, Giri PA. Is India prepared for an impending epidemic of cancers? Int $\mathrm{J}$ Community Med Public Health 2015;2:1-2. 